\author{
В. Г. САіпченко, А. Г. Помягушко, В. О. Котунов \\ Національний технічний університет України \\ «Київський політехнічний інститут імені Ігоря Сікорського» \\ проспект Перемоги, 37, 03056 Київ, Україна
}

\title{
Реєстрація параметрів автоматизованого програмно-апаратного комплексу медичного призначення
}

\begin{abstract}
Наведено опис способів збору і обробки даних під час проведення сеансів тренувань для визначення складу газової гіпоксичної сумімі та стану системи дихання і гемодинаміки (пульсоксиметр) людини. Проаналізовано способи фільтрації сигналів від шумів з різних видів датчиків автоматизованого програмно-апаратного комплексу медичного призначення та запропоновано основні модулі блоку керування комплексу для проведення лікувально-діагностичних прочедур, а саме інтервальних нормобаричних гіпоксичних тренувань. Описано комплекс програмного забезпечення, який пройшов випробування в реальних умовах $i$ рекомендований МOЗ для застосування в лікувальних $i$ спортивних установах з метою підвищення резистентності організму до різних видів навантаження.
\end{abstract}

Ключові слова: блок керування, мікроконтролер, медичний пристрій, інтервальні нормобаричні гіпоксичні тренування, ПІД-регулятор, пульсоксиметрія, спірометрія.

\section{Вступ}

Останнім часом широкого використання в медичній і спортивній практиках набувають інтервальні нормобаричні гіпоксичні тренування (ІНГТ). Це немедикаментозний метод підвищення резистентності організму до специфічного (пониження концентрації кисню) та неспецифічного збудника стресу. Для проведення ІНГТ використовуються спеціальні пристрої - гіпоксикатори. Більшість з існуючих гіпоксикаторів створюють газову гіпоксичну суміш необхідного складу та подають іiї пацієнтові, але не виконують діагностику стану пацієнтів під час сеансів, що знижує безпечність використання гіпоксикаторів та уповільнює поширення методології у державних і приватних клініках, поліклініках, медичних центрах і спортивних секціях [1]. Тому актуальною є задача розробки гіпоксикатора з можливістю діагностики стану пацієнта в реальному часі під час сеансів. Для проведення діагностики стану пацієнта під час гіпоксичного впливу обрано параметри

(C) В. Г. Сліпченко, А. Г. Полягушко, В. О. Котунов 
гемодинаміки (частота серцевих скорочень і сатурація крові) та системи дихання (об’єм дихання, частота дихання та хвилинний об'єм дихання) пацієнта, оскільки ці системи швидше за все реагують на зміну вмісту повітря, що вдихає людина, та можуть бути виміряні неінвазивними методами за допомогою вимірювальних пристроїв.

\section{Постановка задачі}

Метою даної статті є опис особливостей реалізації збору і обробки інформації з вимірювальних пристроїв блоку управління автоматизованого програмноапаратного комплексу (АПАК) у реальному часі під час проведення процедур ІНГТ. Для цього необхідно вирішити наступні задачі:

1) проаналізувати способи фільтрації сигналів, зокрема, відокремити корисний сигнал від шумів з різних видів датчиків та обрати оптимальний варіант 3 урахуванням поставлених задач;

2) реалізувати визначення концентрації газів у газовій гіпоксичній суміші, що вдихає людина, та підтримку встановленого вмісту газів;

3) реалізувати визначення параметрів гемодинаміки та дихальної системи пацієнта під час сеансів ІНГТ;

4) забезпечити збір та обробку даних мікроконтролером у режимі реального часу.

\section{Результати досліджень}

АПАК для проведення гіпокситерапії [2], загальний вигляд якого показано на рис. 1, складається 3 дихальної камери, блоку управління та системи подачі газової суміші пацієнтові [3].

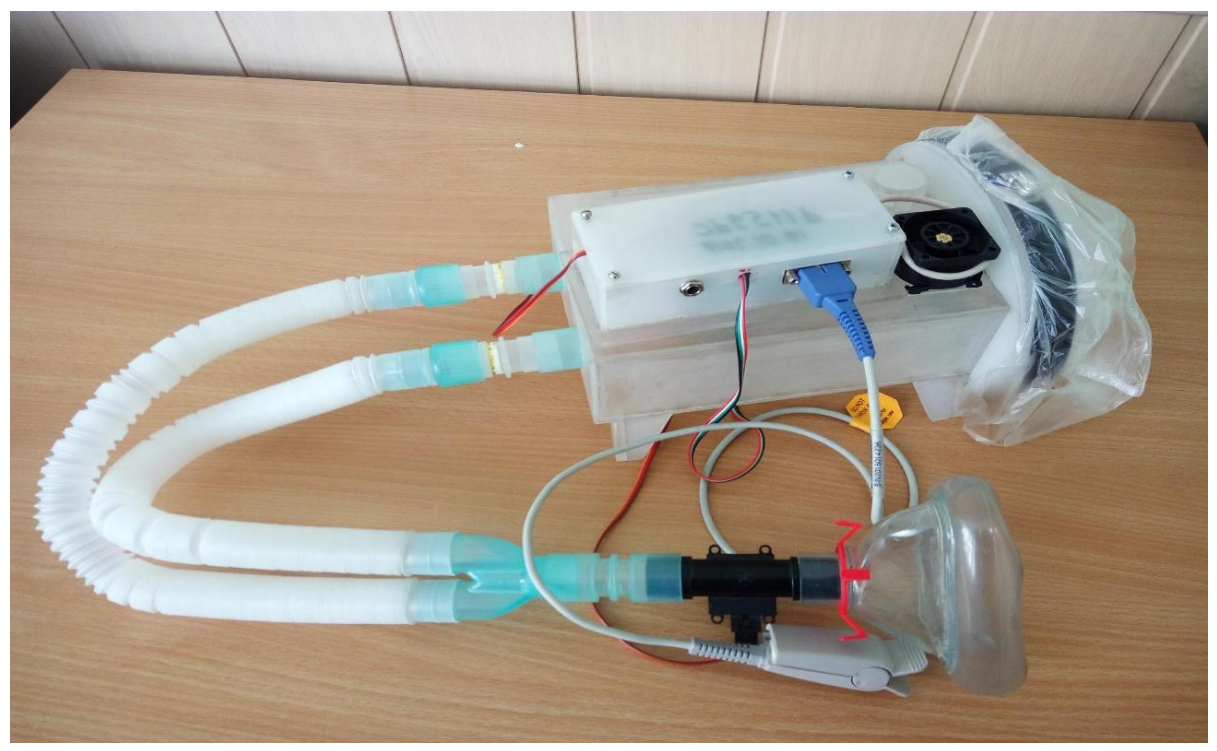

Рис. 1. Автоматизований програмно-апаратний комплекс для гіпокситерапії

Основні функції розробленого програмного забезпечення (ПЗ) мікроконтролера блоку керування медичного пристрою показано на рис. 2. 


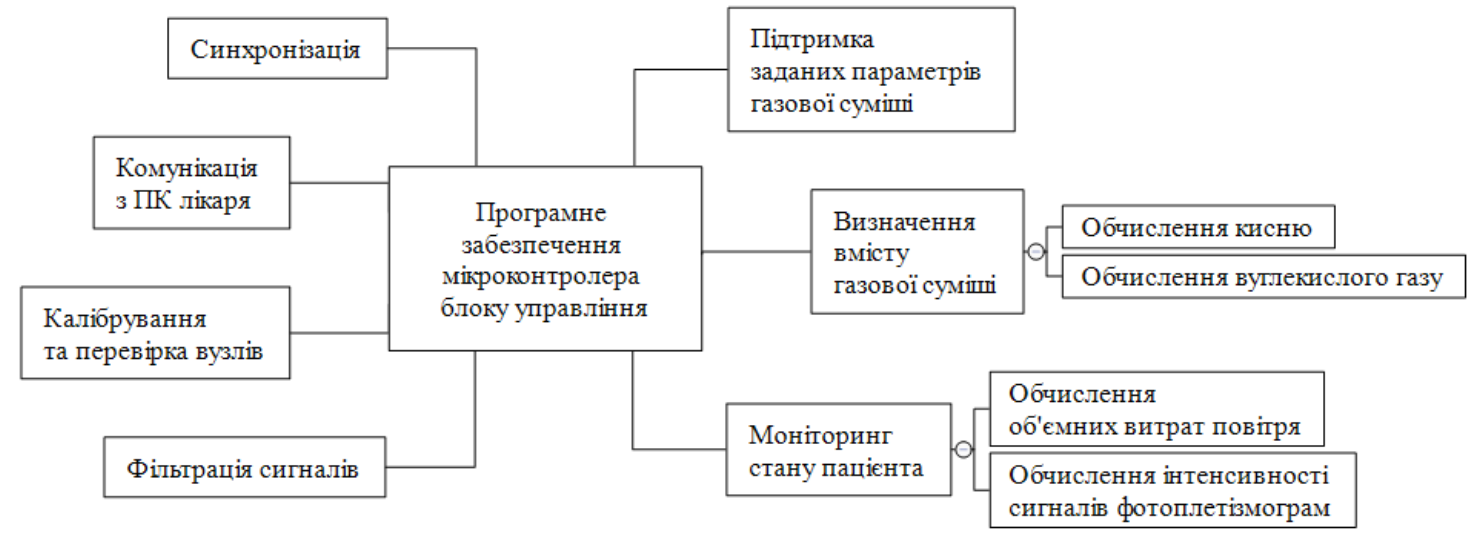

Рис. 2. Функціональна декомпозиція програмного забезпечення блоку управління

Далі розглянемо реалізацію основних блоків ПЗ більш детально.

\section{Фікьтрація сигналів}

При обробці даних з аналого-цифрового перетворювача (АЦП) вимірювальних приладів часто виникає необхідність у фільтрації сигналу, зокрема, відокремленні корисного сигналу від шумів [4]. Враховуючи апаратні особливості платформи, на якій реалізована дана робота, в результаті дослідження різних типів цифрових фільтрів було відібрано фільтр нижніх частот (ФНЧ) Баттерворта 2-го порядку для підсистеми пульсоксиметрії (при обчисленні фотоплетізмограми $(\Phi П Г))$. Такий фільтр можна реалізувати як апаратно, так і програмно. Недоліком апаратної реалізації є складність зміни налаштувань, а також неможливість встановлення у вже створений пристрій. Програмна реалізація такого фільтра не вимагає значних обчислювальних ресурсів і потребує значення сигналу лише на двох останніх ітераціях.

Для дослідження ефективності різних типів цифрових фільтрів було створено тестове програмне забезпечення, результати роботи якого подано на рис. 3.

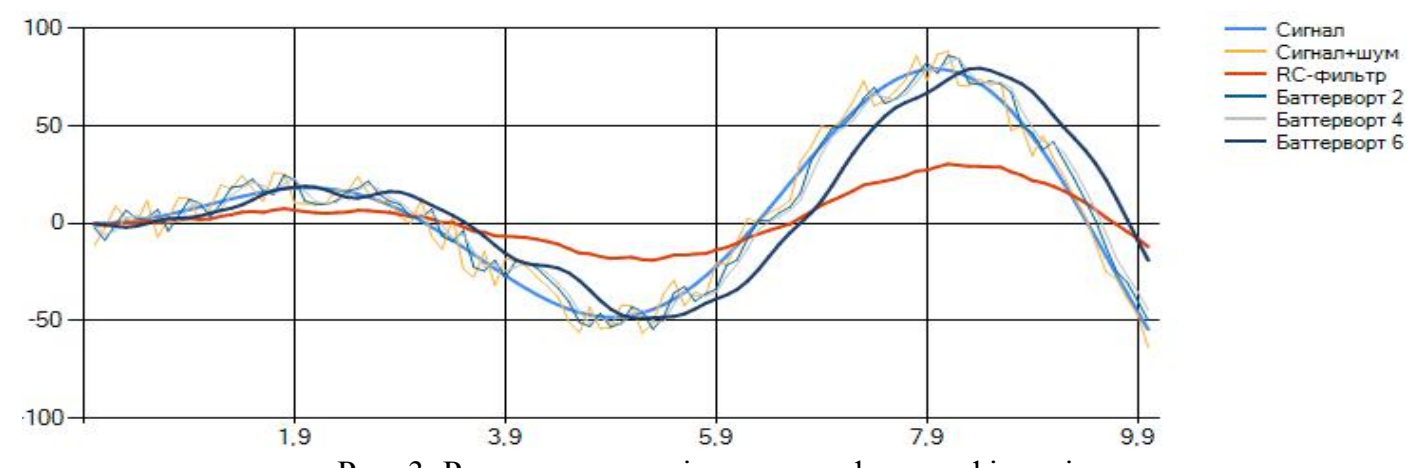

Рис. 3. Результати дослідження цифрових фільтрів

Як видно з графіка на рис. 3, найкращий результат дає ФНЧ Баттерворта 6го порядку, але він потребує значних витрат обчислювальних ресурсів. RC-фільтр зі значним коефіцієнтом має добрі властивості фільтрації, але значно спотворює 
амплітуду сигналу. Необхідно відзначити відставання фази вихідного сигналу для всіх фільтрів.

\section{Обчислення концентрації кисню}

Для визначення концентрації кисню в дихальній суміші використано електрохімічний датчик кисню Figaro KE-25 (Японія). Він створює електрорушійну силу (ЕРС), що прямо пропорційна концентрації кисню у повітрі дихального контуру. Після підсилення цей сигнал надходить на вхід АЦП мікроконтролера. Залежність напруги, виміряної АЦП від виміряної концентрації кисню, виражається формулою

$$
U=k_{\text {cer }} k_{\text {nidc }} k_{\text {aun }} P,
$$

де $k_{c e r}, k_{n i d c}, k_{\text {aun }}$ - коефіцієнти перетворення сенсора, підсилення та перетворення АЦП відповідно. Перемноживши їх і виразивши одним числом $k$, отримаємо формулу для розрахунку концентрації кисню

$$
U=k P,
$$

звідки виміряна концентрація дорівнює:

$$
P=\frac{U}{k} .
$$

У зв'язку з тим, що характеристика даного сенсора може змінитися з часом, у пристрої передбачено можливість калібрування атмосферним повітрям (20,9 \% кисню) та перерахунку коефіцієнта пропорційності:

$$
k=\frac{U}{20,9 \%}[B / \%]
$$

Якщо після калібрування розраховане значення коефіцієнта пропорційності виходить за задані межі - користувач отримає повідомлення про те, що датчик кисню є непридатним для подальшого використання і потребує заміни.

\section{Обчислення концентрації вуглекислого газу}

Датчик концентрації вуглекислого газу $\left(\mathrm{CO}_{2}\right)$ аналогічний датчику кисню, але містить вбудований електронагрівач. Для стабільної електрохімічної реакції $\mathrm{i}$ коректних вимірів перед початком роботи датчик має прогрітися (30 хв. при кімнатній температурі). Під час прогріву датчик має знаходитись у середовищі з концентрацією вуглекислого газу не більше 0,04 \% (атмосферне повітря). Завершення прогріву і готовність до роботи апарат визначає автоматично, аналізуючи зміну ЕРС на виході датчика. Залежність ЕРС від концентрації вуглекислого газу визначається за формулою

$$
\varepsilon=\varepsilon_{0}-\frac{R T}{2 F} \ln (P)
$$

де $\varepsilon_{0}$ - ЕРС за відсутності вуглекислого газу - визначається індивідуально для кожного сенсора і становить 200-600 мB; P - парціальний тиск вуглекислого га- 
зу; $T$ - абсолютна температура; $R$ - універсальна газова стала; $F$ - стала Фарадея. Оскільки за нормальних умов експлуатації температура чутливого елемента $\epsilon$ сталою і визначається вбудованим нагрівачем, то для розрахунків рекомендується використовувати наступну формулу:

$$
\varepsilon=\varepsilon_{0}-\frac{\Delta \varepsilon}{(\lg 400-\lg 1000)}(\lg C-\lg 400),
$$

де $\Delta \varepsilon$ - експериментально визначена різниця між ЕРС на виході датчика при концентраціях вуглекислого газу $0,04 \%$ та 0,1 \% (складає 30-90 мВ); $C$ - виміряна концентрація вуглекислого газу в $\mathrm{ppm}(1 \mathrm{ppm}=0,0001 \%)$.

\section{Підтримка заданих параметрів суміші}

АПАК для гіпокситерапії має певні технічні особливості, що виключають можливість використання традиційного пропорціонально-інтегрально-диференціального регулятора (ПІД-регулятора) [5]. Датчик концентрації кисню має значну інертність, тому диференціювання його показів дасть швидкодію самого датчика, а не швидкість зміни концентрації кисню, і не може бути використано для розрахунку диференціальної складової. Виконуючий пристрій - компресор підкачки атмосферного повітря — може лише підвищувати концентрацію кисню в дихальній камері. Зменшення концентрації здійснюється за рахунок метаболізму пацієнта. У зв'язку з цим, величина концентрації кисню буде постійно коливатися в околі заданого значення, а тому немає необхідності у компенсації статичної помилки i, як наслідок, немає потреби в інтегральній складовій. У той же час, через різну швидкість метаболізму у різних пацієнтів необхідно враховувати швидкість зміни концентрації кисню в дихальній суміші, тобто використання диференціальної складової.

Швидкість зменшення концентрації кисню в дихальному контурі можна опосередковано визначити через хвилинний об'єм дихання. Тому диференціальна складова обчислюється як функція від хвилинного об'єму дихання (рис. 4).

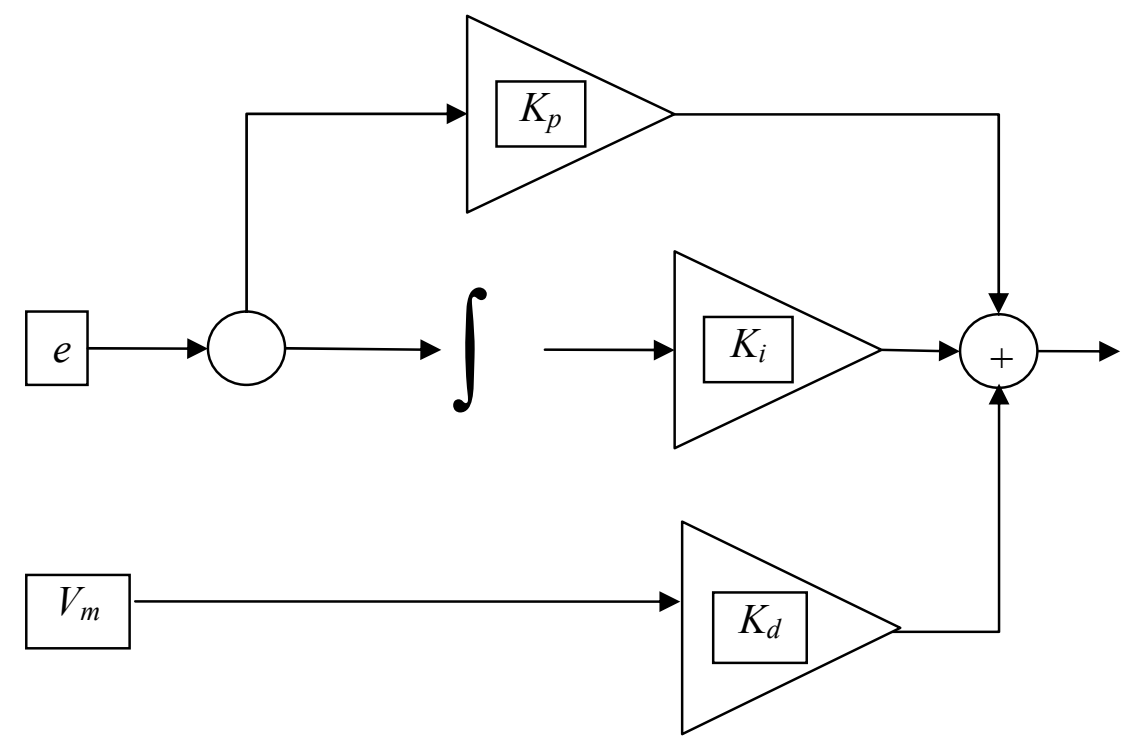

Рис. 4. Функціональна схема реалізованого ПІД-регулятора 
На схемі (рис. 4) $K_{p}, K_{i}, K_{d}$ - пропорційний, інтегральний і диференціальний коефіцієнти регулятора, відповідно. На відміну від традиційної реалізації, диференціальна складова $V_{m}$ надходить окремим значенням, а не розраховується як похідна від нев'язки $e$.

\section{Обчислення параметрів Аихання}

Швидкість потоку вдихуваного та видихуваного повітря вимірюється датчиком об'ємних витрат повітря, що заснований на вимірюванні перепаду тиску при проходженні повітря через діафрагму. Сигнал з електронного дифманометра підсилюється та фільтрується апаратними засобами, після чого подається на АЦП мікроконтролера, який виконує обчислення об’єму вдиху/видиху та вимірювання частоти дихання. Спосіб перетворення значення диференціального тиску на швидкість потоку залежить від конструкції і параметрів вимірювального елемента: трубки або діафрагми. Швидкість потоку визначається за формулою

$$
Q=C_{e} \sqrt{2 \rho \Delta P C_{e}},
$$

де $\Delta P$ - виміряний диференціальний тиск; $\rho-$ густина газу; $C_{e}-$ коефіцієнт, що визначається експериментально. Для розрахунку об'єму виконується чисельне інтегрування швидкості потоку за час одного вдиху або видиху:

$$
V=\int_{t_{1}}^{t_{2}} Q d t,
$$

де $t_{1}$ та $t_{2}$ - час початку та завершення видиху. Вони визначаються як моменти переходу кривої респірації через смугу, що визначає відсутність дихання.

Дана система забезпечує вимірювання об'ємів вдиху/видиху від 250 мл до 6 л і частоти дихання від 5 до 30 хв $^{-1}$. Ці межі призначені для відкидання хибних і зашумлених вимірів i, за необхідності, можуть налаштовуватися програмно користувачем.

\section{Пумьсоксиметрія}

У крові людини існує декілька форм гемоглобіну, в даній роботі розглядаються лише дві: оксигемоглобін (оксигенований, $\mathrm{HbO}_{2}$ ) та дезоксигемоглобін (відновлений, $\mathrm{Hb}$ ). Відношення кількості $\mathrm{HbO}_{2}$ до загальної кількості гемоглобіну називається сатурацією крові $\left(\mathrm{SaO}_{2}\right)$. Неінвазійне вимірювання сатурації крові можна здійснити за допомогою пульсоксиметра, який містить фотоплетізмографічний датчик (ФПГ-датчик). Цей датчик складається з двох світловипромінюючих діодів, які працюють у різних областях спектра (один - у червоній, а інший — в інфрачервоній) і фотоприймача. Конструктивно датчик виконується таким чином, що при його розташуванні на поверхні тіла людини на фотоприймач поступає світло випромінювачів, що послаблене ділянкою тканини, яка містить артеріальну судину.

Висока крутизна спектральної характеристики абсорбції $\mathrm{Hb}$ i $\mathrm{HbO}_{2}$ в області червоного та інфрачервоного випромінювань вимагає розкиду центральної довжини хвилі випромінювання світлодіодів, що використовуються у датчику. Для 
червоного діапазону довжина хвилі випромінювання повинна знаходитись у межах $660 \pm 5$ нм, для інфрачервоного - $940 \pm 10$ нм.

За законом Бугера-Ламберта-Бера обчислюється коефіцієнт передачі $R$ :

$$
R=\left(\ln \frac{I_{d c, r}}{I_{a c, r}}\right):\left(\ln \frac{I_{d c, i r}}{I_{a c, i r}}\right),
$$

де $I_{d c}$ - абсолютне значення інтенсивності світла; $I_{a c}$ - амплітудне значення інтенсивності світла для червоного ( $r$ ) та інфрачервоного (ir) каналів.

При виробництві пульсоксиметрів технологічний розкид довжини хвилі може бути більший, тому часто вводиться корекція калібрувальної залежності, що пов'язує відношення $R$ та значення сатурації [6].

Фотоприймач перетворює інтенсивність послабленого тканинами червоного та інфрачервоного випромінювань на електричний сигнал, який надходить у тракт підсилення. Випромінювачі датчика вмикаються по черзі, тобто комутуються 3 частотою порядку 1000 Гц, що дозволяє використовувати для реєстрації випромінювання один фотоприймач, який комутується. Далі в підсилювальному тракті сигнали червоного та інфрачервоного випромінювань розділяються на два канали за допомогою імпульсів керування комутатора, що переключають світлодіоди. У кожному каналі проводиться вимірювання двох складових ФПГ-сигналу, що зумовлені постійною та пульсуючою складовими абсорбції. Ці дві складові ФПГсигналу необхідні для обчислювання величини коефіцієнта $R$ та визначення сатурації за калібрувальною кривою.

Особливістю підсилювального тракту є необхідність підсилення сигналів фотоприймача у достатньо великому динамічному діапазоні вхідних сигналів (більше ніж 60 дБ). Ця вимога зумовлена значним розкидом оптичних характеристик шкіри, тканин, на які впливають пульсації кровотоку в місті розташування датчика у різних пацієнтів.

Реалізація потрібного динамічного діапазону досягається використанням цифрової системи автоматичного регулювання підсилення (АРП), що охоплює каскади посилення ФПГ-сигналу та джерела струму, що живить світлодіоди. Система АРП підтримує вихідні сигнали підсилювальною тракту на рівні номінальної напруги входу АЦП обчислювача з метою зменшення суми квантування [7].

\section{Синхронізація даних}

Уся взаємодія з програмним забезпеченням мікроконтролера здійснюється через протокол Modbus. Телеметрія передається через Input-регістри, зміна налаштувань реалізована через Holding-регістри, через які також передаються команди керування та параметри, що зберігаються лише в оперативній пам'яті. Всі налаштування зберігаються в енергонезалежній ЕEPROM-пам'яті. Слід зазначити, що в програмі дані представлені числами з плаваючою комою: Modbus-регістри - 16-бітові беззнакові числа, EЕPROM - 8-бітні регістри. Модуль синхронізації даних забезпечує конвертацію типів даних, їхню актуалізацію, передачу між різними типами сховищ і збереження в енергонезалежній пам'яті. Так, при запуску системи, дані з EЕPROM завантажуються у внутрішнє сховище та Modbus-регістри. Телеметрія із внутрішнього сховища постійно копіюється в Input-регістри. Да- 
ні Holding-регістрів навпаки - постійно копіюються у внутрішнє сховище. Якщо Master-пристрій змінив вміст будь якого Holding-регістру, дані з нього скопіюються у відповідний елемент масиву внутрішнього сховища. Залежно від того, які саме дані було змінено, може бути виконана відповідна команда керування апараTом, або дані будуть записані у EEPROM. Окрім цього, модуль синхронізації даних забезпечує верифікацію інформації у EEPROM за допомогою перевірки контрольної суми CRC32.

\section{Таймери, переривання та подіiі}

Мікроконтролер, на якому реалізована описувана система, має один одноядерний центральний процесор. Також у ньому відсутні апаратні та програмні засоби забезпечення декількох потоків виконання програми. Але система вимагає виконання деяких елементів програми в реальному часі, а також розв'язання задач різної складності (з точки зору використання обчислювальних ресурсів) і з різними пріоритетами. Вирішення поставлених завдань забезпечує система апаратних таймерів і переривань, функціональне призначення та режими роботи яких можуть бути задані програмно.

Розглянемо приклад роботи системи на часовій діаграмі (рис. 5). Таймер1 має найвищий пріоритет і блокуючий обробник переривання, він призначений для визначення рівних інтервалів часу, сам обробник займає малу кількість машинного часу та виконує найпростіші операції.

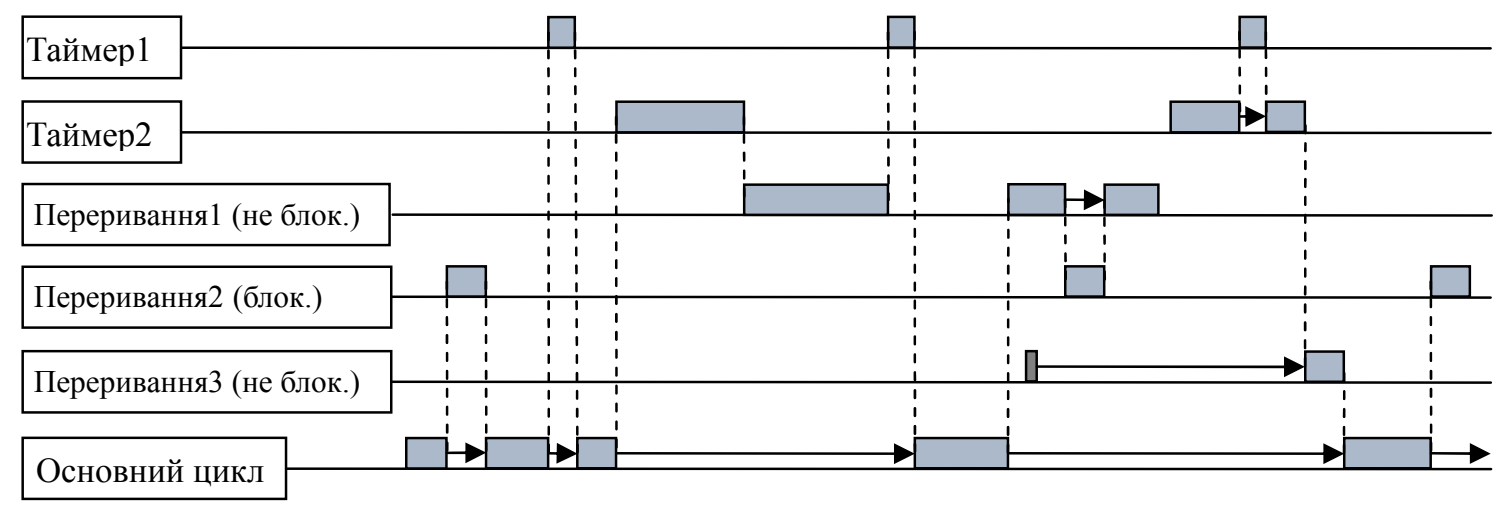

Рис. 5. Часова діаграма

Блокуючий обробник переривання означає, що в разі його спрацювання під час обробки іншого обробника переривання, останній буде призупинено, доки перший блокуючий обробник не завершить свою роботу. У разі спрацювання неблокуючого переривання, обробники виконуються по черзі, відповідно до пріоритетів. Кожному перериванню користувачем може бути призначено один з чотирьох пріоритетів: «вимкнено», «низький», «середній» і «високий». Для вирішення колізій однакових користувацьких пріоритетів існує загальна таблиця всіх векторів переривань, в якій указано пріоритет кожного окремого переривання відносно всіх інших. 
Таким чином, обробник Таймера1 завжди виконується повністю і в заданий момент часу. Таймер2 запускає переривання також через задані інтервали часу, але оскільки він $є$ неблокуючим, його роботу може перервати обробник Таймера1. Після завершення обробника Таймера1 роботу обробника Таймера2 буде продовжено.

Окрім таймерів, переривання може викликати й інша вбудована периферія (АЦП, інтерфейси, зовнішні сигнали), яка спрацьовує у довільні моменти часу, але має ту ж саму систему пріоритетів, що й переривання від таймерів. На графіку (рис. 5) зображено роботу низькопріоритетного Переривання3, воно спрацьовує під час роботи більш пріоритетного Переривання 1, але не виконується, очікує завершення Переривання 1, Переривання 2 та Таймера2, і лише після цього виконується.

Основний цикл працює в ті моменти, коли процесор не зайнятий обробниками переривань. У ньому виконуються значні ресурсоємні операції, що не потребують обробки в реальному часі. Якщо деяка операція має запускатися по перериванню, але не потребує виконання в реальному часі, то в обробнику переривання встановлюється лише «прапорець», по якому в основному циклі буде виконана сама операція, без прив'язки до часу. Якщо після виконання обробника 3 найменшим пріоритетом залишаються необроблені переривання, то їх буде виконано на наступному колі.

Окрім цього, для забезпечення автоматичного виконання часто вживаних команд керування периферією, мікроконтролер має апаратну систему так званих «подій» і систему прямого доступу до пам'яті. Після програмного налаштування ці системи забезпечують виконання простих операцій периферійними пристроями (такі як зміна режиму роботи, передача або збереження даних) без використання центрального процесора.

Враховуючи описані особливості роботи, в розробленому програмному забезпеченні широко застосовуються кінцеві автомати станів. Це забезпечує збереження стану виконуваних процедур при перемиканні між ними у ході роботи програми [8].

\section{Висновки}

3 урахуванням особливостей предметної області (підвищення резистентності організму до різних типів навантаження) у статті отримано такі науковопрактичні результати:

- реалізовано спосіб підтримки заданої концентрації дихальної суміші та керування компресором за допомогою модифікованого ПІД-регулятора, в якому диференціальна складова визначається як функція від хвилинного об'єму дихання;

- досліджено існуючі алгоритми частотної фільтрації, проведено порівняння різних типів програмних фільтрів, проаналізовано можливість їхнього використання у системі ІНГТ та обрано для підсистеми пульсоксиметрії програмний фільтр Баттерворта 2-го порядку, оскільки він не потребує значних обчислювальних ресурсів і використовує значення сигналів лише з двох останніх ітерацій;

- використано систему апаратних таймерів і переривань, функціональне призначення та режими роботи яких можуть бути задані програмно для забезпе- 
чення роботи в реальному часі, а також розв'язання задач різної складності та 3 різними пріоритетами.

Також розроблено блок управління АПАК для проведення гіпокситерапії, що в реальному часі під час сеансів збирає та проводить обробку даних з різних вимірювальних пристроїв, а саме газоаналізаторів (датчиків кисню та вуглекислого газу), пульсоксиметра та датчика вимірювання перепадів тиску.

АПАК з реалізованим програмним забезпеченням [9] пройшов клінічні дослідження та отримав методичні рекомендації MO3 [10] на використання для оздоровлення та лікування в лікувально-профілактичних установах, санаторіях, оздоровчих центрах, а також у наукових цілях.

1. Гіпоксія як метод підвищення адаптаційної здатності організму: монографія/Коркушко О.В. та ін./за заг. ред. О.В. Коркушко, В.Г. Сліпченко. Київ: НТУУ «КПІ», 2015. 482 с.

2. Автоматизований програмно-апаратний комплекс для проведення гіпоксичних тренувань: пат. 123682 Україна: МПК (2006) А61М 16/00. № u201707302; заявл. 11.07.2017; опубл. 12.03.2018, Бюл. № 5/2018.

3. Slipchenko V., Poliagushko L., Kotunov V. Development og hardware and software of the complex for hypoxytherapy. Technology audit and production reserves. 2018. N 2. C. 22-28.

4. Оппенгейм А., Шафер Р. Цифровая обработка сигналов. Москва: Техносфера, 2006. 856 с. ISBN 5-94836-077-6.

5. Денисенко В.В. Компьютерное управление технологическим процессом, экспериментом, оборудованием. Москва: Горячая линия-Телеком, 2009. 608 с.

6. Строев В.М., Куликов А.Ю., Фролов С.В. Проектирование измерительных медицинских приборов с микропроцессорным управлением: учеб. пособ. - Тамбов: Изд-во ФГБОУ ВПО «ГГТУ», 2012.96 c

7. Котунов В.О., Полягушко Л.Г. Визначення сатурації крові пульсоксиметричним способом та програмний аналіз фотоплетізмограми. Сучасні проблеми наукового забезпечення енергетики: тези доповідей ХІІІ Міжнар. наук.-практ. конф. Київ, 2015. Т. 2. С. 174.

8. Хилл Ф. Программирование микроконтроллеров. Санкт-Петербург: Питер, 2002. 1088 с.

9. Свідоцтво авторського права на твір: комп’ютерна програма «Система супроводу інтервальних нормобаричних гіпоксичних тренувань». Л.Г. Полягушко, В.Г. Сліпченко, В.О. Котунов. № 75868 від 12.01.2018.

10. Застосування інтервальних нормобаричних гіпоксичних тренувань у хворих похилого віку з хронічним обструктивним захворюванням легень: метод. рек. (42.17/86.17)/уклад.: Е.О. Асанов, В.Г. Сліпченко, Л.Г. Полягушко та ін. Київ: КПІ ім. Ігоря Сікорського: Вид-во «Політехніка», 2017. $28 \mathrm{c}$. 